\title{
Controlling Liverwort and Moss Now and in the Future
}

Jason C. Fausey

Additional INDEX wOrds. flumioxazin, oxyfluorfen, oxadiazon, weed competition, containerized ornamental

SummaRY. The liverwort, marchantia (Marchantia polymorpha), and silver thread moss (Bryum argenteum) are two highly invasive and difficult to control pests in containerized ornamentals. Container trials were conducted evaluating marchantia and silve $\mathbf{r}$ thread moss control with preemergence and postemergence applications of chlorothalonil, captan, ammonium chlorides, hydrogen dioxide, flumioxazin, oxyfluorfen, pelargonic acid, acetic acid (vinegar), copper sulfate, cinnamaldehyde, prodiamine, and oxadiazon. Flumioxazin, oxyfluorfen, pelargonic acid, acetic acid, and oxadiazon provided acceptable preemergence and/or postemergence marchantia and silver thread moss control; however, no product provided acceptable control of these weeds at all evaluations. Under controlled environmental conditions marchantia and silver thread moss were controlled with flumioxazin, oxyfluorfen, pelargonic acid, acetic acid, and oxadiazon. In addition to providing postemergence control of these weeds, flumioxazin, oxyfluorfen, and oxidiazon also had residual activity when applied to potting media. However, the length and effectiveness of the preemergence control with flumioxazin, oxyfluorfen, and oxadiazon was dependant upon formulation. In a separate study comparing granular and sprayable formulations of flumioxazin, oxyfluorfen, and oxidiazon, results indicated control of established marchantia and silver thread moss was greater with sprayable formulations when compared with granular formulations. Similarly, sprayable formulations of these active ingredients enhanced residual marchantia and silver thread moss control. The granular and sprayable formulations of flumioxazin provided greater preemergence and postemergence control of marchantia and silver thread moss when compared with granular or sprayable formulations of oxyfluorfen and oxadiazon, and of the products evaluated, displayed the greatest level of activity against these weeds.

W eed control is a leading cultural dilemma every nursery manager producing container plants faces. Weeds seriously impact growth and survival of desirable plants. In addition to reducing plant fitness, aesthetics of a crop are also correlated with the presence of weeds, and container-grown ornamentals commonly are commercially unacceptable if weeds are present (Chase and Osborne, 1984).

Although weed control is a challenge in the production of all nursery plants, it is especially problematic in propagation. Many products registered for use on established ornamentals are injurious to newly established plants. Additionally, the large range of ornamental species in production presents a challenge for pesticide manufactures, as each plant must be tested under various production practices prior to adding it to the label. This limits the number of plants listed on the label (Mervosh and Ahrens, 1998). Consequently growers are often left with limited weed-management strategies for specific groups of ornamentals.

Several difficult to control weeds have spread throughout the United States nursery industry at an alarming rate. Two such weeds are marchantia and silver thread moss. Although reasons for the spread of these weeds are not always clear, ornamental liners infested with marchantia or silver thread moss are commonly produced in one region of the country, transported to another region for finishing, and shipped again to a retail location. Plants acquire and disseminate weeds at each point of transfer.

Valent U.S.A. Corporation, 1333 N. California Blvd., Suite 600, Walnut Creek, CA 94596. 
One important aspect of weed management, especially for managing marchantia and silver thread moss, is to prevent conditions that allow these weeds to become established. The presence of either species in containerized growing areas requires an additional level of monitoring to ensure the problem does not become epidemic (Hammett, 1976). However, this is increasingly difficult with over 6,000 species of liverworts naturally occurring in moist temperate regions throughout the world (Crum, 1991). Even if both weeds are controlled following establishment, removal of the dead or dying debris is required before shipping.

Managing weeds in a container nursery involves eliminating weeds and preventing their spread in the nursery. Preemergence herbicides are frequently applied to the soil surface to prevent weed establishment; however, they should not be the only management tool implemented. Maximizing cultural and mechanical controls by the use of proper sanitation and hand weeding are two important means in preventing the rapid spread and regeneration of these troublesome weeds.

Research trials evaluating the effects of traditional fungicides, insecticides, and disinfectants on marchantia and silver thread moss have been conducted (Chase, 2000; Chase and Osborn 1984; Hammett, 1976). Varying interpretations of these results have led to confusion among growers. Trials often conclude a single application of a single product will eliminate concerns with marchantia and silver thread moss, although this is not always the case.

Research comparing marchantia and silver thread moss control in containerized ornamentals is limited. Published research from the field has not documented the relative effectiveness or the ideal time to apply products for controlling these weeds. Several commercial and experimental herbicides including cyclic imides, diphenyl ethers, oxadiazoles, and triazolinones inhibit protoporphyrinogen oxidase (Protox), an enzyme that converts protoporphyrinogen IX to protoporphyrin IX in chlorophyll biosynthesis (Duke et al., 1990). Flumioxazin, oxyfluorfen, and oxadiazon are Protox inhibiting herbicides currently being developed or in use to manage marchantia and silver thread moss in containerized ornamentals. The objectives of this research were to evaluate marchantia and silver thread moss control with several pesticides including insecticides, fungicides, and disinfectants, and compare their control to herbicide applications.

\section{Materials and methods}

General methods for experl-

MENTS. Plastic l-qt (0.95-L) containers were filled with BACCTO (Michigan Peat Co., Houston, Texas) potting soil at Sawyer Nursery in Hudsonville, Mich., in May 2000. Containers were separated into two groups based on the presence or absence of natural infestations of marchantia and silver thread moss. A $50-\mathrm{mL}$ (1.7-fl oz) slurry consisting of a 1:1 (by volume) ratio of marchantia and silver thread moss to water was applied to containers that were free of marchantia and silver thread moss. Containers were grown under a natural photoperiod without supplemental lighting. Following application, containers were fertilized with $50 \mathrm{~mL}$ of a water-soluble fertilizer solution [400 $\operatorname{ppm}\left(\mathrm{mg} \cdot \mathrm{L}^{-1}\right) \mathrm{N}, 174.8 \mathrm{ppm} \mathrm{P}$, and 332 $\mathrm{ppm} \mathrm{K]}$, and watered as needed. Spray treatments were applied with a compressed backpack sprayer traveling at 1.3 miles $/ \mathrm{h}\left(2.09 \mathrm{~km} \cdot \mathrm{h}^{-1}\right)$ and delivering $200 \mathrm{gal} /$ acre $\left(1870 \mathrm{~L} \cdot \mathrm{ha}^{-1}\right)$ at 40 $\mathrm{lb} /$ inch $^{2}(276 \mathrm{kPa})$ of pressure. Treatments were applied with 8005 flat-fan nozzles (Spraying Systems Co., Wheaton, Ill.) spaced 20 inches $(50.8$ $\mathrm{cm})$ apart and held 19 inches $(48.3 \mathrm{~cm})$ above the media or weed surface. Granular treatments were applied with a handheld shaker jar. Treatments were applied to the containers immediately following application of the slurry or directly to established marchantia and silver thread moss averaging 1 to 2 inches $(2.5$ to $5.1 \mathrm{~cm})$ in height.

Each experiment was a completely randomized design with four replications per treatment. Marchantia and silver thread moss control were visually evaluated in each experiment. Visual ratings were based on a scale from $0 \%$ to $100 \%$, with $0=$ no control and $100=$ plant death. Evaluations represented visible stunting, chlorosis, and necrosis.

Study 1. Experiments compared the sensitivity of marchantia and silver thread moss to commercial formulations of various pesticides. Treatments included an untreated control, l qt/ 100 gal $\left(2.5 \mathrm{~mL} \cdot \mathrm{L}^{-1}\right)$ chlorothalonil (Daconil Zn; Syngenta, Greensboro, N.C.), 2 qt $/ 100$ gal $\left(5.0 \mathrm{~mL} \cdot \mathrm{L}^{-1}\right)$ captan (Captec 4L; Micro Flo Co., Memphis, Tenn.), $50 \mathrm{fl} \mathrm{oz} / 100 \mathrm{gal}\left(3.9 \mathrm{~mL} \cdot \mathrm{L}^{-1}\right)$ ammonium chlorides (Triathlon; Olympic Horticultural Products, Bradenton, Fla.), 2 gal/100 gal (20.0 $\mathrm{mL} \cdot \mathrm{L}^{-1}$ ) hydrogen dioxide (ZeroTol; BioSafe Systems, Glastonbury, Conn.), $2 \mathrm{lb} /$ acre $\left(2.2 \mathrm{~kg} \cdot \mathrm{ha}^{-1}\right)$ a.i. oxyfluorfen (Goal; Dow AgroSciences, Indianapolis, Ind.), $0.34 \mathrm{lb} /$ acre $\left(0.381 \mathrm{~kg} \cdot \mathrm{ha}^{-1}\right)$ a.i. flumioxazin (SureGuard; Valent U.S.A. Corp., Walnut Creek, Calif.), 5 $\mathrm{gal} / 100 \mathrm{gal}\left(50.0 \mathrm{~mL} \cdot \mathrm{L}^{-1}\right)$ perargonic acid (Scythe; Mycogen Corp., Indianapolis, Ind.), 8 gal/100 gal (80.0 $\left.\mathrm{mL} \cdot \mathrm{L}^{-1}\right)$ acetic acid (200-grain white distilled vinegar; Nakano Foods Inc., Mount Prospect, Ill. ), $4 \mathrm{lb} / 1,000 \mathrm{ft}^{2}$ $\left(195.3 \mathrm{~kg} \cdot \mathrm{ha}^{-1}\right)$ copper sulfate $(99 \%$ copper sulfate pentahydrate; Phelps Dodge Refining Co., El Paso, Texas), $85 \mathrm{fl} \mathrm{oz} / 100$ gal $\left(6.6 \mathrm{~mL} \cdot \mathrm{L}^{-1}\right)$ cinnamaldehyde (Cinnamite; Mycotech Corp., Butte, Mt.), and $0.5 \mathrm{lb} /$ acre (0.56 $\mathrm{kg} \cdot \mathrm{ha}^{-1}$ ) a.i. prodiamine (Barricade; Syngenta). All treatments were applied 10 May 2000. Visual ratings were recorded weekly for 12 weeks following application.

STUDY 2. Further experiments were conducted at Sawyer Nursery in Hudsonville, Mich., in August 2000. Experiments compared the sensitivity of marchantia and silver thread moss to commercial formulations of both granular and sprayable formulations of oxyfluorfen, flumioxazin, and oxadiazon. Treatments included an untreated control, $2 \mathrm{lb}$ /acre a.i. oxyfluorfen $+1 \mathrm{lb} /$ acre (1.1 kg.ha ${ }^{-1}$ )a.i.oryzalin (Rout; The Scotts Co., Marysville, Ohio), $2 \mathrm{lb} /$ acre a.i. oxyfluorfen (Goal), two formulations of $0.34 \mathrm{lb} /$ acre a.i. flumioxazin (BroadStar; Valent U.S.A. Corp., SureGuard), and two formulations of $4 \mathrm{lb} /$ acre $(4.5$ $\mathrm{kg} \cdot \mathrm{ha}^{-1}$ ) a.i. oxadiazon (Ronstar 50 WSP and Ronstar 2 G; Aventis Environmental Science, Montvale, N.J.). All treatments were applied 10 Aug. 2000.

Statistical analyses. Visual ratings were conducted as previously described and all data were analyzed using analysis of variance. Means were separated by Fisher's protected least significant difference at $P=0.05$.

\section{Results and discussion}

STudy 1. The products evaluated were previously reported to have postemergence activity against marchantia. In this trial control ranged from $0 \%$ to $100 \%$ (Table 1). Marchantia ratings from 18 to 25 May did not differ greatly with the exception of flumioxazin and oxyfluorfen, which had a 2 -fold increase in activity between these dates. In 
our work $80 \%$ control represented the minimum commercially acceptable control, and only flumioxazin, pelargonicacid, and aceticacid achieved thislevel of efficacy against emerged marchantia after 2 weeks.

Results evaluating postemergence silver thread moss control confirm grower reports that Protox inhibiting herbicidessuchasflumioxazin and oxyfluorfen control emerged silver thread moss (Table 1). Results also indicate pelargonic acid effectively controls emerged silver thread moss. However, unlike the postemergence control of marchantia, acetic acid did not provide commercially acceptable control of silver thread moss.

Applying chlorothalonil, captan, ammonium chlorides, copper sulfate, cinnamaldehyde, or prodiamine did not provide commercially acceptable control. These results differ from previously reported work (Chase, 2000) where ammonium chlorides and cinnamaldehyde effectively controlled emerged liverwort and to a lesser degree, moss. Chase (2000) also reported captan did not provide commer- cially acceptable liverwort or moss control, but did provided activity against algae.

Preemergence marchantia control ratings on 15 June indicated acetic acid and prodiamine reduced marchantia populations $50 \%$ and $45 \%$, respectively, compared to the untreated control (Table 2). Eleven weeks after application, on 27 July, no visible preemergence marchantia control was observed with acetic acid or prodiamine. In contrast, oxyfluorfen and flumioxazin displayed greater than $98 \%$ marchantia control 8 weeks after application, and $58 \%$ and $74 \%$ preemergence marchantia control 11 weeks after application, respectively.

Results from this study indicated that none of the products tested completely prevent infestations from occurring nor eliminate them once present although oxyfluorfen, flumioxazin, pelargonic acid, and aceticacid can be used most effectively to manage marchantia and or silver thread mossinfestations. Due to the vast diversity in marchantia populations, results may vary between popula- tions and further testing is warranted to confirm these findings.

STUdY 2. All products evaluated provided significant preemergence and postemergence control of marchantia compared to the untreated control.

Greater preemergence marchantia control was achieved with the sprayable formulation of oxyfluorfen than with the granular formulation, although formulation did not affect marchantia control with flumioxazin or oxadiazon (Table 3). In contrast, preemergence silver thread moss control was not affected by the formulation of oxyfluorfen, flumioxazin, or oxadiazon. The disparity in the performance of the two oxyfluorfen formulations could be explained by the use rate of the granular formulation. Granular oxyfluorfen was applied at $100 \mathrm{lb}$ of product per acre (112.1 kg.ha-1) whereas the granular formulations of flumioxazin and oxadiazon were applied at $200 \mathrm{lb}$ of product per acre $\left(224.2 \mathrm{~kg} \cdot \mathrm{ha}^{-1}\right)$.

Ratings taken on 7 and 19 Sept.

Table 1. Postemergence control of marchantia and silver thread moss with various products applied $10 \mathrm{May} \mathrm{2000.}{ }^{\mathrm{Z}}$

\begin{tabular}{|c|c|c|c|c|c|}
\hline \multirow[b]{3}{*}{ Product } & \multirow[b]{3}{*}{ Rate } & \multicolumn{4}{|c|}{ Control (\%) } \\
\hline & & \multicolumn{2}{|c|}{ Marchantia } & \multicolumn{2}{|c|}{ Silver thread moss } \\
\hline & & 18 May & 25 May & 18 May & 25 May 25 \\
\hline Chlorothalonil & $1 \mathrm{qt} / 100 \mathrm{gal}\left(2.5 \mathrm{~mL} \cdot \mathrm{L}^{-1}\right)$ & $8 \mathrm{gh}$ & $3 \mathrm{~g}$ & $0 \mathrm{e}$ & $0 \mathrm{e}$ \\
\hline Captan & $2 \mathrm{qt} / 100 \mathrm{gal}\left(5.0 \mathrm{~mL} \cdot \mathrm{L}^{-1}\right)$ & $9 \mathrm{gh}$ & $11 \mathrm{fg}$ & $4 \mathrm{e}$ & $6 \mathrm{e}$ \\
\hline Ammonium chlorides & $50 \mathrm{fl} \mathrm{oz} / 100 \mathrm{gal}\left(3.9 \mathrm{~mL} \cdot \mathrm{L}^{-1}\right)$ & 36 cde & $31 \mathrm{e}^{\mathrm{s}}$ & $15 \mathrm{de}$ & $9 \mathrm{de}$ \\
\hline Flumioxazin & a.i. $0.34 \mathrm{lb} /$ acre $\left(0.381 \mathrm{~kg} \cdot \mathrm{ha}^{-1}\right)$ & 41 cde & $83 \mathrm{bc}$ & $68 \mathrm{~b}$ & $100 \mathrm{a}$ \\
\hline Pelargonic acid & $5 \mathrm{gal} / 100 \mathrm{gal}\left(50.0 \mathrm{~mL} \cdot \mathrm{L}^{-1}\right)$ & $100 \mathrm{a}$ & $95 \mathrm{a}$ & $100 \mathrm{a}$ & $91 \mathrm{ab}$ \\
\hline Acetic acid & $8 \mathrm{gal} / 100 \mathrm{gal}\left(80.0 \mathrm{~mL} \cdot \mathrm{L}^{-1}\right)$ & $79 \mathrm{~b}$ & $85 \mathrm{~b}$ & $65 \mathrm{bc}$ & $35 \mathrm{c}$ \\
\hline Copper sulfate & $4 \mathrm{lb} / 1000 \mathrm{ft}^{2}\left(195.3 \mathrm{~kg} \cdot \mathrm{ha}^{-1}\right)$ & $45 \mathrm{c}$ & $33 \mathrm{e}$ & $8 \mathrm{e}$ & $13 \mathrm{de}$ \\
\hline Cinnamaldehyde & $85 \mathrm{fl} \mathrm{oz} / 100 \mathrm{gal}\left(6.6 \mathrm{~mL} \cdot \mathrm{L}^{-1}\right)$ & $6 \mathrm{gh}$ & $5 \mathrm{fg}$ & $5 \mathrm{e}$ & $3 \mathrm{e}$ \\
\hline Prodiamine & a.i. $0.5 \mathrm{lb} / \operatorname{acre}\left(0.56 \mathrm{~kg} \cdot \mathrm{ha}^{-1}\right)$ & $0 \mathrm{~h}$ & $5 \mathrm{fg}$ & $0 \mathrm{e}$ & $3 \mathrm{e}$ \\
\hline
\end{tabular}

${ }^{\mathrm{z}}$ Significance between products is only to be compared within columns. Values followed by a common letter are not significantly different by Fisher's protected LSD at $P=0.05$.

Table 2. Effects of spraying media before the germination and establishment of marchantia with various products applied on $10 \mathrm{May}$ 2000. ${ }^{\mathrm{z}}$

\begin{tabular}{|c|c|c|c|}
\hline \multirow[b]{2}{*}{ Product } & \multirow[b]{2}{*}{ Rate } & \multicolumn{2}{|c|}{ Marchantia control (\%) } \\
\hline & & 15 June & 27 July \\
\hline Untreated control & & $0 \mathrm{c}$ & $0 \mathrm{c}$ \\
\hline Chlorothalonil & $1 \mathrm{qt} / 100 \mathrm{gal}\left(2.5 \mathrm{~mL} \cdot \mathrm{L}^{-1}\right)$ & $0 \mathrm{c}$ & $0 \mathrm{c}$ \\
\hline Captan & $2 \mathrm{qt} / 100 \mathrm{gal}\left(5.0 \mathrm{~mL} \cdot \mathrm{L}^{-1}\right)$ & $0 \mathrm{c}$ & $0 \mathrm{c}$ \\
\hline Ammonium chlorides & $50 \mathrm{fl} \mathrm{oz} / 100 \mathrm{gal}\left(3.9 \mathrm{~mL} \cdot \mathrm{L}^{-1}\right)$ & $0 \mathrm{c}$ & $0 \mathrm{c}$ \\
\hline Hydrogen dioxide & $2 \mathrm{gal} / 100 \mathrm{gal}\left(20.0 \mathrm{~mL} \cdot \mathrm{L}^{-1}\right)$ & $0 \mathrm{c}$ & $0 \mathrm{c}$ \\
\hline Oxyfluorfen & a.i. $2 \mathrm{lb} /$ acre $\left(2.2 \mathrm{~kg} \cdot \mathrm{ha}^{-1}\right)$ & $98 \mathrm{a}$ & $58 \mathrm{~b}$ \\
\hline Flumioxazin & a.i. $0.34 \mathrm{lb} / \operatorname{acre}\left(0.381 \mathrm{~kg} \cdot \mathrm{ha}^{-1}\right)$ & $100 \mathrm{a}$ & $74 \mathrm{a}$ \\
\hline Pelargonic acid & $5 \mathrm{gal} / 100 \mathrm{gal}\left(50.0 \mathrm{~mL} \cdot \mathrm{L}^{-1}\right)$ & $0 \mathrm{c}$ & $3 c$ \\
\hline Acetic acid & $8 \mathrm{gal} / 100 \mathrm{gal}\left(80.0 \mathrm{~mL} \cdot \mathrm{L}^{-1}\right)$ & $50 \mathrm{~b}$ & $0 \mathrm{c}$ \\
\hline Copper sulfate & $4 \mathrm{lb} / 1000 \mathrm{ft}^{2}\left(195.3 \mathrm{~kg} \cdot \mathrm{ha}^{-1}\right)$ & $13 \mathrm{c}$ & $0 \mathrm{c}$ \\
\hline Cinnamaldehyde & $85 \mathrm{fl} \mathrm{oz} / 100 \mathrm{gal}\left(6.6 \mathrm{~mL} \cdot \mathrm{L}^{-1}\right)$ & $5 \mathrm{c}$ & $1 \mathrm{c}$ \\
\hline Prodiamine & a.i. $0.5 \mathrm{lb} /$ acre $\left(0.56 \mathrm{~kg} \cdot \mathrm{ha}^{-1}\right)$ & $45 \mathrm{~b}$ & $3 c$ \\
\hline
\end{tabular}

${ }^{\mathrm{z}}$ Significance between products is only to be compared within columns. Values followed by a common letter are not significantly different by Fisher's protected LSD at $P=0.05$ 
and 12 Oct. 2000 indicate the granular formulation of oxyfluorfen did not provide postemergence marchantia control equal to the sprayable formulation of oxyfluorfen. Reduced coverage with the granular formulation or an antagonistic effect of adding oryzalin to oxyfluorfen in the granular formulation could be responsible for these results. Research by Hammett (1996) reported dinitroaniline herbicides such as oryzalin have little effect on marchantia growth, and the results with the dinitroaniline herbicide, prodiamine, in study l support this work (Table 1). However, work by Senesac and Tsontakis-Bradley (1997) found that oryzalin alone was effective in controlling marchantia. This trial suggests that the reduced postemergence marchantia control with the granular oxyfluorfen formulation was a result of reduced coverage.

Statistically, the granular and sprayable formulations of flumioxazin provided identical postemergence marchantia control (Table 4). However, at each evaluation the sprayable formulation provided numerically greater control than the granular formulation, and this supports the trend that was observed between the oxyfluorfen formulations.

Postemergence marchantia control with oxadiazon differed between formulations and evaluation date (Table 4). Ratings taken on 7 Sept., 4 weeks after application, were not significantly different; however, ratings on 19 Sept. and 12 Oct. showed greater control with the sprayable formulation when compared with the granular formulation.

The use of a Protox-inhibiting herbicide in containerized ornamentals has several benefits. In addition to activity on marchantia and silver thread moss, oxyfluorfen, flumioxazin, and oxadiazon have preemergence activity against other common weeds, such as common groundsel (Senecio vulgaris) and hairy bittercress (Cardamine hirsute). The preventative use of these herbicides provides additional strategies for managing weed resistance from weed escapes and decreases future weed infestations by reducing weed seed return. Although these were single year results, they indicate that further research investigating ornamental tolerance to sprayable formulations of these herbicides would be beneficial for weed management programs in ornamentals.

\section{Literature cited}

Chase, A.R. 2000. The slippery plant pests: algae, moss and liverwort. Greenhouse Product News 10:60-63.

Chase, A.R. and L.S. Osborne. 1984. Controlling algae in foliage plant production. Proc. Fla. State Hort. Soc. 97:274-278.

Duke, S. O., J. M. Becerril, T. D. Sherman, J. Lydon, and H. Matsumoto. 1990. The role of protoporphyrin IX in the mechanism of action of diphenyl ether herbicides. Pesticide Sci. 30:367-378.

Crum, H.A. 1991. Liverworts and hornworts of southern Michigan. Univ. Mich. Herbarium, Ann Arbor.

Hammett K.R. 1976. Control of liverwort growth on the surface of soil in plant containers. N.Z. J. Expt. Agr. 4:117-119.

Mervosh, T.L. and J.F. Ahrens. 1998. Preemergence herbicides for containergrown perennials. Proc. N.E. Weed Sci. Soc. 52:131.

Senesac, A. and I. Tsontakis-Bradley. 1997. Liverwort and pearlwort management in container-grown perennials. Proc. N.E. Weed Sci. Soc. 51:100.

Table 3. Effects of spraying media before establishment of marchantia and silver thread moss with various products applied on 10 Aug. 2000. ${ }^{\mathrm{z}}$

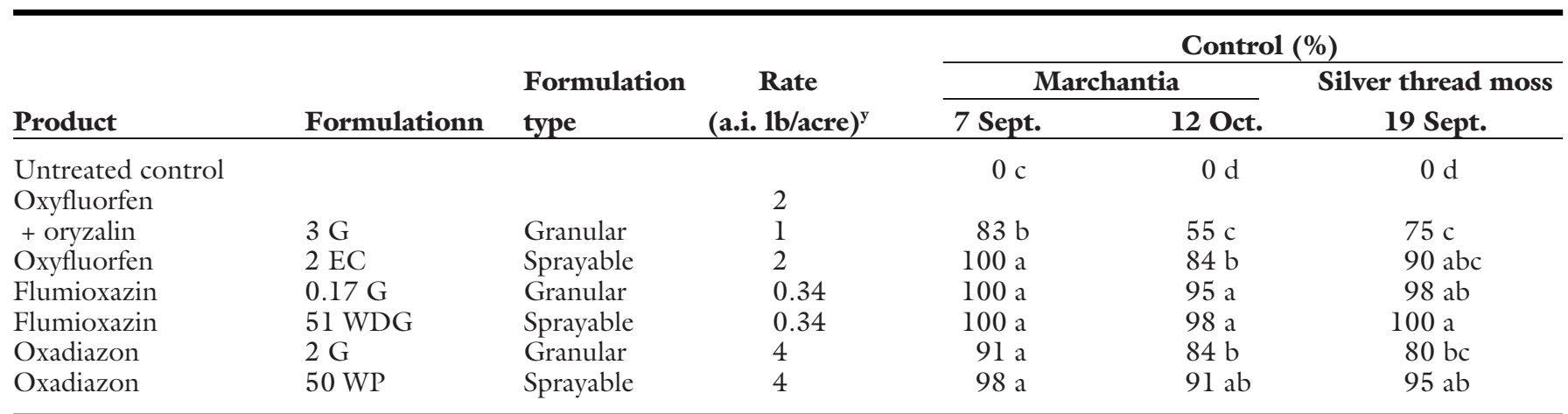

$\overline{{ }^{z}}$ Significance between products is only to be compared within columns. Values followed by a common letter are not significantly different by Fisher's protected LSD at $P=0.05$. y $1.00 \mathrm{lb} /$ acre $=1.121 \mathrm{~kg} \cdot \mathrm{ha}^{-1}$.

Table 4. Postemergence marchantia control with various products applied on 10 Aug. $2000 .^{\mathrm{z}}$

\begin{tabular}{|c|c|c|c|c|c|c|}
\hline \multirow[b]{2}{*}{ Product } & \multirow[b]{2}{*}{ Formulation } & \multirow{2}{*}{$\begin{array}{l}\text { Formulation } \\
\text { type }\end{array}$} & \multirow{2}{*}{$\begin{array}{c}\text { Rate } \\
\text { (a.i. 1b/acre })^{y}\end{array}$} & \multicolumn{3}{|c|}{ Marchantia control (\%) } \\
\hline & & & & 7 Sept. & 19 Sept. & 12 Oct. \\
\hline $\begin{array}{l}\text { Untreated control } \\
\text { Oxyfluorfen }\end{array}$ & & & 2 & $0 \mathrm{e}$ & $0 \mathrm{~d}$ & $0 \mathrm{e}$ \\
\hline + oryzalin & $3 \mathrm{G}$ & Granular & 1 & $33 \mathrm{~d}$ & $60 c$ & $60 \mathrm{~d}$ \\
\hline Oxyfluorfen & $2 \mathrm{EC}$ & Sprayable & 2 & $84 \mathrm{bc}$ & $81 \mathrm{~b}$ & $80 c$ \\
\hline Flumioxazin & $0.17 \mathrm{G}$ & Granular & 0.34 & $88 \mathrm{ab}$ & $90 \mathrm{a}$ & $95 \mathrm{a}$ \\
\hline Flumioxazin & $51 \mathrm{WDG}$ & Sprayable & 0.34 & $93 \mathrm{a}$ & $98 \mathrm{a}$ & 97 a \\
\hline Oxadiazon & $2 \mathrm{G}$ & Granular & 4 & $79 \mathrm{c}$ & $80 \mathrm{~b}$ & $88 \mathrm{~b}$ \\
\hline Oxadiazon & $50 \mathrm{WP}$ & Sprayable & 4 & $80 \mathrm{c}$ & $90 \mathrm{a}$ & $94 \mathrm{a}$ \\
\hline
\end{tabular}

${ }^{\mathrm{z}}$ Significance between products is only to be compared within columns. Values followed by a common letter are not significantly different by Fisher's protected LSD at $P=0.05$. ${ }^{y} 1.00 \mathrm{lb} /$ acre $=1.121 \mathrm{~kg} \cdot \mathrm{ha}^{-1}$. 